Research Article/Araştırma Makalesi

\title{
The Effect of Reading Comprehension, Interpretation and Four Operations Skills on Student Success in Velocity Subject of $6^{\text {th }}$ Grade Science Course
}

\author{
İbrahim KARASU *1 (iD) Mehmet Akif HAŞILOĞLU 2 (D)

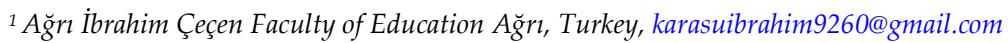 \\ 2 A ̆̆r İbrahim Çeçen Faculty of Education Ağrr, Turkey, mehmet.hasiloglu@hotmail.com \\ * Corresponding Author: karasuibrahim9260@gmail.com
}

\begin{tabular}{|c|c|}
\hline Article Info & Abstract \\
\hline $\begin{array}{l}\begin{array}{l}\text { Received: } 22 \text { November } 2019 \\
\text { Accepted: }\end{array} \text { 26 February } 2020 \\
\text { Keywords: Four operation skills, } \\
\text { reading comprehension and } \\
\text { interpretation, velocity, power and } \\
\text { movement, academic science success } \\
\text { doi) 10.18009/jcer.649866 } \\
\text { Publication Language: Turkish }\end{array}$ & $\begin{array}{l}\text { The aim of this study is to analyze whether there is a relationship } \\
\text { between reading comprehension, interpretation of reading, four } \\
\text { operation skills and academic achievements in velocity topic of Science } \\
\text { Course of the 6th grade students. Therefore, the research is conducted } \\
\text { as a descriptive-correlative study in the relational model. As a result of } \\
\text { parametric tests applied after determining that data range is normal; it } \\
\text { is seen that there is a positive correlation respectively r=0,522 (medium } \\
\text { level) r }=0684 \text { (so close to the high level), between reading } \\
\text { comprehension, interpretation, four operation skills and academic } \\
\text { science success. Lastly, four operation skills and reading } \\
\text { comprehension, interpretation achievement together can explain that } \\
\text { the variance of science achievement at the rate of } 48,4 \% \text {, is reached. }\end{array}$ \\
\hline CrossMark CC & $\begin{array}{l}\text { To cite this article: Karasu, İ. \& Haşıloğlu, M.A. (2020). Okuduğunu } \\
\text { anlama yorumlama ve dört işlem becerisinin 6. sinıf fen bilimleri } \\
\text { dersi sürat konusundaki öğrenci başarısına etkisi. Journal of Computer } \\
\text { and Education Research, 8(15), 136-155. DOI:10.18009/jcer.649866 }\end{array}$ \\
\hline
\end{tabular}

\section{Okuduğunu Anlama Yorumlama ve Dört İşlem Becerisinin 6.Sınıf Fen Bilimleri Dersi Sürat Konusundaki Öğrenci Başarısına Etkisi}

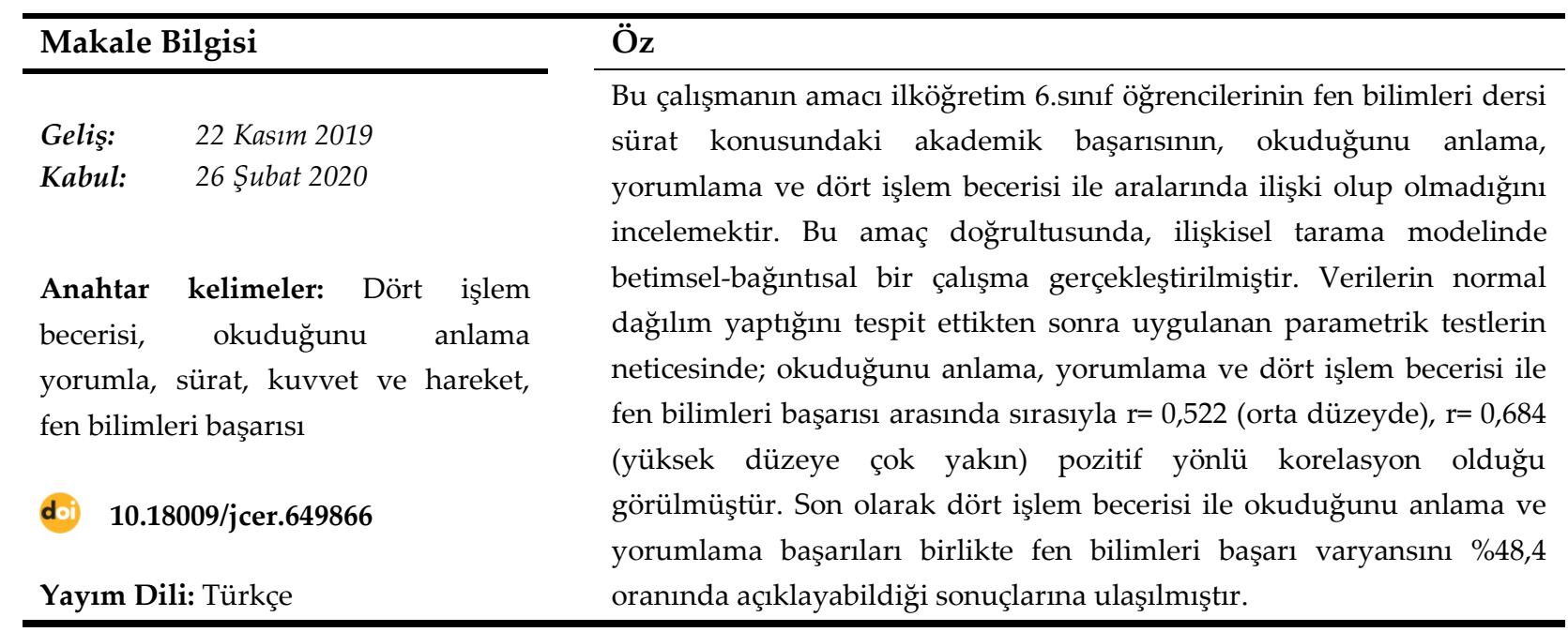




\section{Summary}

\section{The Effect of Reading Comprehension, Interpretation and Four Operations Skills on Student Success in Velocity Subject of $\boldsymbol{6}^{\text {th }}$ Grade Science Course}

\section{Introduction}

Individuals who have a good level of reading comprehension and interpretation skills will be able to achieve success not only in Turkish language lessons but also in many disciplines such as science and mathematics. (Sever, 1993; Kutlu, Yıldırım, Bilican \& Kumandas, 2011; Büyüköztürk, Çakan, Tan, \& Atar, 2014). From this perspective, it is thought that reading comprehension and interpretation skills have an effect on academic achievement in science course.

The aim of this study was to determine the level of effect of four processing skills and reading comprehension and interpretation of the 6th grade students on answering a 20-item academic achievement test on the subject of speed in the force and motion unit of science lesson. In addition, the relationship between the tests and the descriptive results of students' reading comprehension and interpretation, numerical ability test that measures four processing skills and students' achievement in the academic achievement test on speed subject of science course were also examined.

\section{Method}

The study was conducted as a descriptive-correlational study among correlational survey model of quantitative research methods. In correlational studies, it is examined whether there is a relationship between multiple variables (Karasar, 2000).

The population of the research is Eleşkirt district of Ağr1 province in Turkey. The sample of the study consists of $2456^{\text {th }}$ grade students in Eleşkirt district of Ağrı province in 2017-2018 academic year. 245 students who participated in the study were determined using appropriate sampling method. The number of students who participated in all tests was 224 students. 21 students were not included in the study due to missing and / or incorrect data. 
In the study, 3 different tests were applied as data collection tool. These are reading comprehension and interpretation test, numerical ability test, force and movement (subject of speed) academic achievement test.

A 20-item multiple-choice skill test, from the master thesis of Cereno (1998), was used. Calculated item statistics were recalculated by the researcher as they were available from the available data and to be applied on a different sample group. It was applied to approximately 100 people, $6^{\text {th }}$ grade students, and item statistics were calculated by extracting missing and incorrect data. According to the data obtained, the substance discrimination index (Rjx) of this 20 -item test ranges from 0.31 to 0.68 . The item difficulty index $(\mathrm{Pj})$ varies between 0.30 and 0.77 . In addition, the mean difficulty index $(\mathrm{Pj})$ of the test was calculated as 0.56 , while the mean discrimination index (Rjx) was calculated as 0.46 . Pearson correlation coefficient was calculated as 0.97 and Spearman correlation coefficient was calculated as 0.99 .

In order to measure the numerical ability and four processing skills of the students, the 20-item multiple-choice skill test developed by Cereno's (1998) was recalculated by the researcher because the calculated item statistics would be applied to the available data and it was going to be applied to a different sample group. After the necessary examinations, the test was applied to approximately $1006^{\text {th }}$ grade students, and the missing and / or incorrect data were extracted, and item statistics were calculated. As a result of the application, the final discriminant index (Rjx) of this test, which was finalized with 20 items, was calculated as 0.31 as the lowest and 0.68 as the highest. The item difficulty index (Pj) varies between 0.21 and 0.78 .

Science class $6^{\text {th }}$ grade speed subject of force and motion unit academic achievement test This achievement test was developed by the researcher based on the subject of speed of force and motion the unit in the 6th grade science curriculum in the 2017-2018 academic year. During the test development phase, items with an item discrimination index (Rjx) below 0.20 and above 0.90 were removed. As a result of the application, the final discriminant index (Rjx) of this test was found to be 0.31 as the lowest and 0.62 as the highest, and the item difficulty index $(\mathrm{Pj})$ ranged between 0.23 and 0.62 . Pearson correlation coefficient was calculated as 0.94 and Spearman correlation coefficient was calculated as 0.97 . 


\section{Discussion and Conclusion}

In line with the results obtained in this study, reading comprehension and interpretation and four processing skills had a positive effect on the academic achievement scores on the speed subject of science course. There was a positive relationship between Turkish language course and science at medium level and mathematics and science at very high level. When we look at the predictive power of our independent variables (Turkish and Mathematics) and dependent variable (Science), the results show that the ability of comprehension and interpretation of reading can predict the academic achievement of speed subject in science course by $27.2 \%$ and four processing skills predicted $46.8 \%$ academic achievement and it also shows the close relationship of these disciplines with each other. The fact that mathematics predicts academic success in speed subject of science course is close to $50 \%$ indicates that there is a need for cooperation between these two disciplines. Although the subject of speed is a numerical content, the importance of the ability to understand and interpret a reading power of $27.2 \%$ on the academic success of the science course on speed cannot be denied. 


\section{Giriş}

Öğrenci başarı düzeyini belirlemek için yapılan TiMSS (Trends in International Mathematics and Science Study) ve PİSA (Programme for International Student Assessment) gibi sınavlarda Türk öğrencilerinin, fen bilimleri, matematik ve okuduğunu anlama başarılarının, diğer katılımcı ülkelerin başarı ortalamalarına göre daha düşük olduğu görülmektedir (Milli Eğitim Bakanlığı [MEB], 2006, 2010, 2015). Fen bilimleri eğitimindeki başarının yetersizlik sebeplerini araştıran (Şad, 2012) çalışmalar neticesinde; okuduğunu kavramanın da akademik başarı üzerinde önemli ölçüde etkisinin olduğu görülmüştür.

Okuduğunu anlama, yorumlama ve kavrama becerisi iyi düzeyde olan bireyler, sadece türkçe dersinde değil, fen bilimleri, matematik gibi birçok disiplinde de başarı elde edebilecektir (Sever, 1993; Kutlu, Yıldırım, Bilican \& Kumandas, 2011; Büyüköztürk, Çakan, Tan, \& Atar, 2014). Bloom (1995)'un yapmış olduğu araştırmada öğrencilerin, okuduğunu anlama becerisinin, fen bilimleri ve edebiyat gibi derslerdeki başarıları arasında ilişki olduğu görülmüştür. Bu açıdan bakıldığında okuduğunu anlama ve yorumlama becerisinin, fen bilimleri dersindeki akademik başarı üzerinde etkisi olduğu düşünülmektedir.

Uluslararası yapılan TİMSS ve PİSA gibi sinavlardan elde edilen bulgulara baktığımızda matematik ve fen bilimleri derslerindeki başarı ortalamaları arasında bir paralellik olduğunu görmekteyiz (MEB, 2006, 2010, 2015). Alan yazına bakıldığında (Çavaş, 2002 akt: Deveci, 2010) fen bilimleri derslerinde karşılaşılan problemlerin bir bölümünün matematik temelli olduğu ifade edilirken, Güleç ve Alkış (2003),'ın yaptıkları araştırmada da fen bilimleri ve matematik dersleri arasında pozitif yönde yüksek bir korelasyon olduğu sonucuna ulaşmışlardır. Bunun yanında, Bütüner ve Uzun (2011), yaptıkları çalışmada; öğrencilerin, fen bilimleri dersinde matematikten kaynaklanan sorunlardan dolayı sıkıntı çekilen fen bilimleri dersi konularını ve yüzdeliklerini incelemiştir. Öğretmenlerle yapmış oldukları anketten elde edilen bulgular neticesinde; kuvvet-hareket, sürat ve basit makineler öğrencilerin, matematik kaynaklı sıkıntılardan dolayı en fazla sorun yaşadıkları konular olduğu görülmüştür (Bütüner \& Uzun, 2011).

\section{Araştırmanın Önemi ve Amacı}

Literatür incelendiğinde öğrencilerin, türkçe ve matematik derslerindeki başarılarının birlikte fen bilimleri dersi başarısı üzerinde nasıl etki ettiğini inceleyen çalışma sayısının çok sınırlı olduğu görülmüştür. Bunun yanında yapılan literatür taramasında Türkiye'deki 
araştırmalarda; genel başarının aksine daha spesifik olan sürat konusundaki öğrenci başarılarını ve başarılarına bağlı etkenleri araştıran pek bir çalışmaya rastlanılmadığı gibi sürat konusundaki öğrenci başarısını etkileyen faktörlerin regresyon analizlerinin yapıldığ1 bir çalışmaya da rastlanılmamıştır. Bütüner ve Uzun (2011) ile Ciminli'nin (2013) yapmış oldukları çalışmalarda öğretmenlerin görüşleri doğrultusunda öğrencilerin sürat konusunda yaşadıkları sorunların matematik temelli olduklarını belirtmelerinden hareketle bu araştırmada, yaşanan matematik temelli sıkıntıların ne ölçüde ya da ne düzeyde etki ettiği incelenmek istenmiştir. Kısaca bu araştırmada, literatürdeki eksiliği gidermek amacıyla ilköğretim 6.sınıf öğrencilerinin; okuduğunu anlama, yorumlama ve dört işlem becerilerinin, sürat konusundaki akademik başarılarını nasıl etkilediği incelenmiştir. Böylece çalışmanın alana katkı sağlayacağı düşünülmektedir.

\section{Araștırmanın Problem Cümlesi}

İlköğretim 6.sınıf öğrencilerinin okuduğunu anlama, yorumlama ve dört işlem becerilerinin fen bilimleri dersi sürat konusundaki akademik başarılarına etkisi nedir?

1. İlköğretim 6.sınıf öğrencilerinin fen bilimleri dersi sürat konusundaki akademik başarıları ile okuduğunu anlama ve yorumlama becerileri arasında anlamlı bir ilişki var mıdır?

2. İlköğretim 6.sınıf öğrencilerinin fen bilimleri dersi sürat konusundaki akademik başarıları ile sayısal yetenek becerileri arasında anlamlı bir ilişki var mıdır?

3. İlköğretim 6.sınıf öğrencilerinin okuduğunu anlama ve yorumlama başarıları ile sayısal yetenek başarıları ayrı ayrı fen bilimleri dersi sürat konusundaki akademik başarıyı anlamlı bir şekilde yordamakta mıdır?

4. İlköğretim 6.sınıf öğrencilerinin okuduğunu anlama, yorumlama ve sayısal yetenek testlerindeki başarıları birlikte fen bilimleri dersi sürat konusundaki akademik başarıyı anlamlı bir şekilde yordamakta mıdır?

\section{Yöntem}

\section{Araştırmanın Modeli}

$\mathrm{Bu}$ araştırmada okuduğunu anlama, yorumlama ve dört işlem becerisinin; 6.sınıf öğrencilerinin fen bilimleri dersinin sürat konusundaki akademik başarılarına etkisinin ne düzeyde olduğu incelenecektir. Bu yüzden araştırma, ilişkisel tarama modelinde nicel araştırma yöntemlerinden betimsel-bağıntısal bir çalışma olarak gerçekleştirilmiştir. Betimsel 
araştırmalarda araştırmanın evreni belirlenir ve bu evrenden bir örneklem alınarak, örneklem bir ya da birkaç değişken açısından incelenir. Bağıntısal modelde değişkenler; bir araştırmada incelenen özelliklerin her biridir. Örneğin, öğrenci başarısı, öğretmen kişiliği, öğretim yöntemi $\mathrm{vb}$. toplanan verilerin istatistiksel tekniklerle incelenmesi sonucunda, değişkenler arasında bir bağıntı olup olmadığı belirlenir (Karasar, 2000).

Bir durum hakkında olabildiğince dikkatli ve detaylı bir şekilde tanımlama yapan betimsel araştırma, bireylerin ve grupların özelliklerini kolayca özetlediğinden eğitim alanında yaygın olarak kullanılır (Büyüköztürk vd., 2013). İlişkisel tarama modelinde nicel araştırma yöntemlerinden betimsel-bağıntısal olarak çalışılan bu araştırmada; araştırma probleminde yer alan iki ya da daha fazla değişkene ilişkin olarak örneklemdeki katılımcılardan veri toplanmıştır.

\section{Evren ve Örneklem}

Araştırmanın evrenini Ağrı ilinin Eleşkirt ilçesi oluşturmaktadır. Örneklemini ise 2017-2018 Eğitim Öğretim yılında Ağrı ili Eleşkirt ilçesinde bulunan ilköğretim 6.sınıf öğrencilerinden 245 öğrenci oluşturmaktadır. Çalışmaya katılan 245 öğrenci uygun örnekleme yöntemi kullanılarak belirlenmiştir. Uygun örnekleme yöntemi, zaman, para ve iş gücü bakımından oluşabilecek sınırlılıkları azaltması sebebiyle tercih edilen bir yöntem (Büyüköztürk vd., 2013) olduğundan bu araştırmada testlerin kolay uygulanabileceği ve evreni temsil edebilecek şekilde hem başarı hem de sosyoekonomik bakımdan düşük, orta ve yüksek düzeyde olan öğrencilerin bulunduğu iki okul seçilmiştir. Uygulanan tüm testlere katılan öğrenci sayısı 224 öğrencidir. Eksik ve/veya hatalı verilerden dolayı 21 öğrenci araştırmaya dâhil edilmemiştir. Katılımcıların \%51,79 i erkek (n=116), \%48,21 si kız (n=108) öğrencilerden oluşmaktadır.

\section{Verilerin Toplanması ve Analizi}

Araştırmada veri toplama aracı olarak 3 ayrı test uygulanmıştır. Bunlar; "Okuduğunu anlama ve yorumlama testi, sayısal yetenek testi, kuvvet ve hareket (sürat konusu) akademik başarı testi" dir.

\section{Okuduğunu Anlama ve Yorumlama Testi}

Öğrencilerin okuduğunu anlama ve yorumlama becerisini ölçmek amaciyla Cereno'nun (1998) yapmış olduğu yüksek lisans tezi çalışmasından alınan 20 maddelik 
çoktan seçmeli beceri testi kullanılmıştır. Hesaplanan madde istatistikleri eldeki hazır verilerden ve farklı bir örneklem grubuna uygulanacağından dolayı araştırmacı tarafından tekrar hesaplanmıştır. İlköğretim 6.sınıf öğrencilerinden oluşan yaklaşık 100 kişiye uygulanıp eksik ve hatalı veriler çıkartılarak madde istatistik hesapları yapılmıştır. Uygulama sonucu elde edilen verilere göre; 20 maddelik bu testin madde ayırt edicilik indeksi (Rjx); 0,31 ile 0,68 arasında değişmektedir. Madde güçlük indeksi (Pj) ise 0,30 ile 0,77 arasında değişmektedir. Ayrıca testin ortalama güçlük indeksi (Pj); 0,56 olarak hesaplanırken, ortalama ayırt edicilik indeksi (Rjx); 0,46 olarak hesaplanmıştır. Pearson korelasyon katsayısı; 0,97, Spearman korelasyon katsayısı; 0,99 olarak hesaplanmıştır. Cereno'ya (1998) göre ise uygulanan bu okuduğunu anlama ve yorumlama testinin madde ayırt edicilik indeksi (Rjx); 0,27 ile 0,78 değerleri arasında değişim gösterirken, madde güçlük indeksi (pj) ise 0,28 ile 0,75 değerleri arasında değişim göstermektedir. Ayrıca ortalama güçlük indeksi (Pj); 0,52 olarak hesaplanırken, ortalama ayırt edicilik indeksi (Rjx); 0,53 olarak hesaplanmıştır. Madde geçerlik ve güvenirlik hesapları yapıldıktan sonra 137 öğrenciye daha uygulama yapılarak tüm veri analizleri hesaplanmıştır.

\section{Sayısal Yetenek Testi}

Öğrencilerin sayısal yetenek ve dört işlem becerisini ölçmek amacıyla Cereno'nun (1998) yapmış olduğu yüksek lisans tezi çalışmasından alınan 20 maddelik çoktan seçmeli beceri testinin hesaplanan madde istatistikleri eldeki hazır verilerden ve farklı bir örneklem grubuna uygulanacağından dolayı araştırmacı tarafından tekrar hesaplamak istenmiştir. Karşılaştırma sonucunda aksi yönde bir sonuca ulaşılmamıştır. Yapılan gerekli inceleme ve düzenlemelerden sonra test, ilköğretim 6.sınıf öğrencilerinden yaklaşık 100 kişiye uygulanıp eksik ve/veya hatalı veriler çıkartılarak madde istatistik hesapları yapılmıştır. Uygulama sonucu 20 madde ile son hali verilen bu testin madde ayırt edicilik indeksi (Rjx) en düşük 0,31, en yüksek ise 0,68 olarak hesaplanmıştır. Madde güçlük indeksi (Pj) ise 0,21 ile 0,78 arasında değişmektedir. Ayrıca testin ortalama güçlük indeksi (Pj); 0,38 olarak hesaplanırken, ortalama ayırt edicilik indeksi (Rjx); 0,41 olarak hesaplanmıştır (Tablo 3.2.). Pearson korelasyon katsayısı: 0,94, Spearman Korelasyon katsayısı: 0,97 olarak hesaplanmıştır. Cereno'a (1998) göre ise uygulanan bu sayısal yetenek beceri testinin madde ayırt edicilik indeksi (Rjx); 0,43 ile 0,75 değerleri arasında değişim gösterirken, madde güçlük indeksi (pj) ise 0,20 ile 0,72 değerleri arasında değişim göstermektedir. Ayrıca ortalama 
güçlük indeksi $(\mathrm{Pj}) ; 0,39$ olarak hesaplanırken, ortalama ayırt edicilik indeksi (Rjx); 0,55 olarak hesaplanmıştır. Madde geçerlik ve güvenirlik hesapları yapıldıktan sonra 137 öğrenciye daha uygulama yapılarak tüm veri analizleri hesaplanmıştır.

Fen bilimleri Dersi 6.Sını Kuvvet ve Hareket Ünitesi Sürat Konulu Akademik Başarı Testi

Bu başarı testi 2017-2018 eğitim öğretim yılı ilköğretim 6.sınıf fen bilimleri ders programında yer alan kuvvet ve hareket ünitesindeki sürat konusundan hareketle araştırmacı tarafından geliştirmiştir. Testin içeriğini oluşturan maddeler $(5,13,14,15,16,17$ ve 19) numaralı maddeler EBA (Url 1) sayfasından alınarak oluşturulurken, (1, 2, 3, 4, 6, 7, 8, 9, 10, 11, 12) numaralı maddeler ise ÖDGSM (Url 2) sayfasından alınmıştır. Ayrıca (Pakyürek Karagöz, 2008)'in geliştirmiş olduğu başarı testinden de (18 ve 20) numaralı sorular alınarak toplamda 20 madde ile testin içeriği belirlenmiştir. Sorular kuvvet ve hareket ünitesinin sürat konusunun tüm kazanımlarını içerecek şekilde hazırlanmıştır. Fen bilimleri akademik başarı testine son halini vermek için testin madde analizleri yapılmıştır. Madde analizi yapılan istatistiksel işlem sonucu testteki her bir sorunun madde güçlük indeksi (Pj) ve madde ayırt edicilik indeks (Rjx) değerleri hesaplanmıştır. Test geliştirme aşamasında, madde ayırt edicilik indeksi (Rjx) 0,20'nin altında, 0,90'ın ise üstünde olan maddeler çıkartılmıştır. Uygulama sonucu 20 maddeyle son hali verilen bu testin madde ayırt edicilik indeksi (Rjx) en düşük 0,31, en yüksek ise 0,62 olarak hesaplanırken, madde güçlük indeksi (Pj) ise 0,23 ile 0,62 arasında değişmekte olduğu görülmüştür. Ayrıca testin ortalama güçlük indeksi (Pj); 0,41 olarak hesaplanırken, ortalama ayırt edicilik indeksi (Rjx); 0,43 olarak hesaplanmıştır (Tablo 3.6.). Pearson korelasyon katsayısı: 0,94, Spearman korelasyon katsayısı: 0,97 olarak hesaplanmiştır.

Uygulanan testler sonucunda ortaya çıkan eksik ve/veya hatalı veriler çıkartılmıştır. Ayrıca sadece her üç teste giren öğrenciler hesaplamaya dâhil edilerek en az bir teste katılmayan öğrenciler hesaplama dışı bırakılmıştır. Böylece tüm testlerin geçerlik ve güvenirlik hesapları yapılarak toplamda 224 öğrenciye uygulama yapılmıştır. Uygulanan 20 'şer soruluk çoktan seçmeli; Okuduğunu anlama ve yorumlama, sayısal yetenek ve kuvvet ve hareket ünitesinden sürat konulu akademik başarı testleri 100 puan üzerinden hesaplanarak elde edilen veriler excel programina girildikten sonra SPSS 22 (Statistical Packet For Social Studies) paket programına aktarılarak tüm veri analizleri yapılmıştır. 
Testlerin normalliğini ölçmek için çarpıklık-basıklık katsayılarına bakılabilir. Ayrıca z-puanlarına, histogram veya saçılım grafiklerine bakılabilir. Çarpıklık ve basıklık katsayılarının -2 ve +2 aralığında olması verilerin normalden aşırı sapmadığının bir göstergesi olarak kabul edilebilir (George \& Mallery, 2010). z-puanlarının -3 ile +3 arasında dağılım göstermesi de yine verilerin normal dağılım yaptığını göstermektedir (Osborne \& Overbay, 2004).

\section{Verilerin Uygulanması}

İlköğretim 6.sınıf öğrencilerine uygulamak için hazırlanan ve her biri 20 soru olan 1 başarı ve 2 beceri testi: Okuduğunu anlama ve yorumlama testi; Sayısal yetenek başarı testi; Kuvvet ve hareket akademik başarı testi 40 'ar dakikalık sürelerle uygulanmıştır. Uygulamaya başlamadan önce tüm öğrencilere testler ve araştırma ile ilgili detaylı bir şekilde açıklama yapılmıştır. Okuduğunu anlama ve yorumlama testi birinci gün tüm öğrencilere uygulandıktan sonra ikinci gün aynı öğrencilere sayısal yetenek beceri testi uygulanmıştır. Son olarak ise kuvvet ve hareket ünitesinden sürat konusu ile ilgili hazırlanmış olan akademik başarı testi ise üçüncü gün yine aynı öğrencilere uygulanmıştır.

Testlerin uygulandığı öğrencilere, gizlilik ilkesinden dolayı birer numara verilmiştir ve öğrenciler, kendilerine verilen numaraları girdikleri her uygulamada testlerin ve optiklerin üzerine kodlamışlardır. Böylece art arda günlerde yapılan testlerin üzerindeki numaralara bakılarak testler gruplandırılmıştır. Örneğin Ahmet isimli öğrenciye 1(bir) numarasını verdiğimizi düşünelim. Ahmet girmiş olduğu tüm uygulamalarda optiklere ve testlere 1(bir) numarasını kodlamıştır. 1(bir) numarası olan üç ayrı testi bir araya toplayarak bunların bir öğrenciye ait olduğu belirlenmiştir. Yapılan üç ayrı testin herhangi birinde numarası olmayan öğrencileri, eksik veriden dolayı hesaplama dışında bıraktık.

Uygulama yapılan öğrencilerin yaş aralığı göz önünde bulundurulduğunda 3 ayrı testin aynı öğrenciye tek seferde uygulanmasının öğrenciye ağır geleceği ve bundan dolayı öğrencilerin testin sonuna doğru soruları cevaplandırırken düşünmeden işaretleme yapabileceği ihtimali düşünüldügüun dolayı testler tek seferde uygulanmamıştır. Zira düşünmeden, gelişi güzel verilen cevaplar araştırmamızın sonucunu olumsuz etkileyecektir. Her ne kadar farklı tür testler aynı gün uygulanmamış olsa da dışsal etkenlerin, sonucu etkilememesi için testlerin uygulamaları arasına sadece birer günlük zaman koyulmuştur. 
Tüm testler uygulanırken aynı koşulların oluşturulmasına dikkat edilmiştir. Böylece dışsal etkilerin sonuca tesiri minimize edilmeye çalışılmıştır.

\section{Bulgular}

Bu bölümde araştırma sonucunda elde edilen bulgulara yer verilmiştir. Araştırmanın birinci ve ikinci alt problemleri doğrultusunda uygulanan testler arasındaki korelasyon ilişkisine bakılmıştır. Üçüncü alt probleme ilişkin, uygulanan okuduğunu anlama, yorumlama ve sayısal yetenek beceri testlerinin kuvvet ve hareket konulu başarı testini ayrı ayrı nasıl açıkladığını incelemek için basit doğrusal regresyon uygulanmıştır. Son olarak dördüncü probleme ilişkin ise uygulanan okuduğunu anlama, yorumlama ve sayısal yetenek beceri testlerinin kuvvet ve hareket konulu başarı testini birlikte nasıl açıkladığını incelemek için çoklu doğrusal regresyon uygulanmıştır.

\section{Uygulanan Başarı Testlerine Ait Betimsel İstatistikler}

İlköğretim 6.sınıf öğrencilerinden 224 öğrenciye uygulanan testlere ait betimsel istatistik sonuçları aşağıdaki tablolarda ifade edilmiştir. Öğrencilerin okuduğunu anlama ve yorumlama testinde elde ettiği sonuçlar doğrultusunda oluşturulan betimsel isatatistikler Tablo 1' de sunulmuştur.

Tablo 1. Okuduğunu anlama ve yorumlama testine ait betimsel istatistikler

\begin{tabular}{llc}
\hline $\mathrm{N}$ & Geçerli & 224 \\
$\mathrm{X}$ & Eksik & 4 \\
Xort $_{\text {Mod }}$ & & 55,18 \\
SS & & 55,00 \\
Varyans & & 55,00 \\
$\mathrm{P}$ & & 19,03 \\
Rj & & 362,300 \\
Çarpıklık Katsayısı & Çarpıklık & 0,56 \\
& Çarpıklık St. Hata & 0,46 \\
Basıklık Katsayısı & Basıklık &, 077 \\
& Basıklık St. Hata &, 163 \\
Ranj & &,- 338 \\
Min. değer & &, 324 \\
Max. değer & & 90 \\
\hline
\end{tabular}

Tablo 1'e göre; 224 6.sınıf öğrencisine uygulanan okuduğunu anlama ve yorumlama testinin aritmetik ortalaması $(\mathrm{X}): 55,18$ olarak hesaplanmıştır. Diğer istatistik sonuçları ise; medyanı(ortanca)Xort:55,00, modu (tepe değer):55,00, standart sapmas1 (SS): 19,03, varyans değeri: 362,300, öğrenci başarı puanlarından en yüksek değer ile en düşük değer arasındaki fark (Ranj):90 olarak hesaplanmıştır. Ayrıca okuduğunu anlama ve yorumlama başarı 
testinin çarpıklık katsayısı (Skewness): ,077, Skewness standart hatası ise; ,163 olarak hesaplanırken, Basıklık katsayısı (Kurtosis): -,338, Kurtosis Standart hatası ise; ,324 olarak hesaplanmıştır. Öğrencilere uygulanan ikinci testimiz sayısal yetenek beceri testidir. Uygulanan bu test sonucunda elde edilen veriler doğrultusunda oluşturulan betimsel istatistikler Tablo 2.'de sunulmuştur.

Tablo 2. Sayısal yetenek beceri testine ait betimsel istatistikler

\begin{tabular}{llc}
\hline $\mathrm{N}$ & Geçerli & 224 \\
$\mathrm{X}$ & Eksik & 4 \\
$\mathrm{X}_{\text {ort }}$ & & 36,85 \\
Mod & & 35,00 \\
$\mathrm{SS}$ & & 40,00 \\
Varyans & & 15,92 \\
$\mathrm{P}$ & & 253,615 \\
Rj & & 0,38 \\
Çarpıklık Katsayısı & Çarpıklık & 0,41 \\
& Çarpıklık St. Hata &, 276 \\
Basıklık Katsayısı & Basıklık &, 163 \\
& Basıklık St. Hata & $-0,44$ \\
Ranj & &, 324 \\
Min. Değer & & 75 \\
Max. Değer & & 0 \\
\hline
\end{tabular}

Tablo 2'ye göre; 224 6.sınıf öğrencisine uygulanan sayısal yetenek beceri testinin aritmetik ortalaması $(\mathrm{X}): 36,85$ olarak hesaplanmıştır. Diğer istatistik sonuçları ise; medyanı(ortanca)Xort:35,00, modu (tepe değer):40,00, standart sapması (SS):15,92, varyans değeri:253,615, öğrenci başarı puanlarından en yüksek değer ile en düşük değer arasındaki fark (Ranj):75 olarak hesaplanmıştır. Ayrıca sayısal yetenek beceri testinin çarpıklık katsayısı (Skewness): ,276, Skewness standart hatası ise; ,163 olarak hesaplanırken, Basıklık katsayısı (Kurtosis): -,044, Kurtosis Standart hatası ise; ,324 olarak hesaplanmıştır.

Öğrencilere uygulanan son testimiz ise kuvvet ve hareket başarı testidir. Uygulanan bu test sonucunda elde edilen veriler doğrultusunda oluşturulan betimsel istatistikler Tablo 3.'te sunulmuştur.

Tablo 3. Kuvvet ve hareket başarı testine ait betimsel istatistikler

\begin{tabular}{lcc}
\hline $\mathrm{N}$ & Geçerli & 224 \\
$\mathrm{X}$ & Eksik & 4 \\
Xort $_{\text {Mod }}$ & 37,41 \\
SS & & 35,00 \\
Varyans & & 40,00 \\
\hline
\end{tabular}


P

$\mathrm{Rj}$

Çarpıklık Katsayısı

Basıklık Katsayısı

Ranj

Min. değer

Max. değer
0

90

Tablo 3'e göre; 224 6.sınıf öğrencisine uygulanan kuvvet ve hareket başarı testinin aritmetik ortalaması (X):37,41olarak hesaplanmıştır. Diğer istatistik sonuçları ise; medyanı(ortanca)Xort:35,00, modu (tepe değer):40,00, standart sapması (SS):16,81, varyans değeri: 282,727, öğrenci başarı puanlarından en yüksek değer ile en düşük değer arasındaki fark (Ranj):90 olarak hesaplanmıştır. Yine uygulanan bu kuvvet ve hareket başarı testinin çarpıklık katsayısı (Skewness): ,316, Skewness standart hatası ise; ,163 olarak hesaplanırken, Basıklık katsayısı (Kurtosis): -,120, Kurtosis Standart hatası ise; ,324 olarak hesaplanmıştır.

Tablo 4. İlköğretim 6. sınıf öğrencilerinin fen bilimleri dersi sürat konusundaki akademik başarısı ile okuduğunu anlama ve yorumlama becerisi arasındaki korelâsyon

Okuduğunu Anlama ve

Yorumlama

\begin{tabular}{llc}
\hline & Pearson Korelâsyonu &, $522^{* *}$ \\
Kuvvet ve Hareket & $\mathrm{P}$ &, 000 \\
& $\mathrm{~N}$ & 224
\end{tabular}

**Korelâsyon 0.01 düzeyinde önemlidir (2 kuyruklu).

Tablo 4'e göre; ilköğretim altıncı sınıf öğrencilerinin fen bilimleri dersi kuvvet ve hareket ünitesinden uygulanan sürat konulu akademik başarı testi puanları ile okuduğunu anlama ve yorumlama beceri puanları arasında $\mathrm{r}=0,522$ düzeyinde doğrusal ve anlamlı $(\mathrm{p}<0,01)$ bir ilişki vardır.

Tablo 5. İlköğretim 6.sınıf öğrencilerinin fen bilimleri dersi sürat konusundaki akademik başarısı ile sayısal yetenek becerisi arasındaki korelâsyon

Sayısal Yetenek

\begin{tabular}{llc}
\hline & Pearson Korelâsyonu &, $684^{* * *}$ \\
Kuvvet ve Hareket & $\mathrm{P}$ &, 000 \\
& $\mathrm{~N}$ & 224 \\
\hline
\end{tabular}

**Korelâsyon 0.01 düzeyinde önemlidir (2 kuyruklu). 
Tablo 5'e göre; ilköğretim altıncı sınıf öğrencilerinin fen bilimleri dersi, kuvvet ve hareket ünitesinden uygulanan sürat konulu akademik başarı testi puanları ile dört işlem becerisini ölçen sayısal yetenek beceri puanları arasında $r=0,684$ düzeyinde doğrusal ve anlamlı $(\mathrm{p}<0,01)$ bir ilişki vardır.

Tablo 6. İlköğretim 6.sınıf öğrencilerinin sayısal yetenek becerisi ile okuduğunu anlama ve yorumlama becerisi arasındaki korelâsyon

\begin{tabular}{llrr}
\hline & & $\begin{array}{c}\text { Okuduğunu } \\
\text { Yorumlama }\end{array}$ & Anlama ve \\
\hline Sayısal & Pearson Korelâsyonu &, $593^{* *}$ \\
Yetenek & $\mathrm{P}$ &, 000 \\
& $\mathrm{~N}$ & 224
\end{tabular}

**Korelâsyon 0.01 düzeyinde önemlidir (2 kuyruklu).

Tablo 6'ya göre ilköğretim altıncı sınıf öğrencilerinin dört işlem becerisi ölçen sayısal yetenek beceri testi puanları ile okuduğunu anlama ve yorumlama beceri puanları arasında $\mathrm{r}=0,593$ düzeyinde doğrusal ve anlamlı $(\mathrm{p}<0,01)$ bir ilişki olduğu ortaya çıkmıştır.

Bu çalışmadaki değişkenler arasındaki korelasyon değerleri tablo 4., 5., ve 6.'da verilmiştir. Tablolardan da görüldüğ̈̈ gibi değişsenler arasındaki korelasyon değerleri 0,90 'ın altında olduğu için çoklu doğrusallık sorununun olmadığı söylenebilir. Tablo 1., 2. Ve 3.'e baktığımızda basıklık ve çarpıklık değerlerinin normal aralıkta olduğunu görmekteyiz. Ayrıca testlerin z-puanlarına baktığımızda; okuduğunu anlama yorumlama testi z-puanı: (2,37355 ile 2,35479), sayısal yetenek tesi z- puanı: (-2,3141 ile 2,39539), kuvvet ve hareket testi z-puanı: (-2,22491 ile 2,88762) olduğunu görmekteyiz. Tüm bu analizler değerlendirildiğinde eldeki verilerin regresyon analizlerinin yapılmasın uygun olduğunu söyleyebiliriz.

Tablo 7. İlköğretim 6.sınıf öğrencilerinin matematik (sayısal yetenek) başarı notlarının fen bilimleri başarı notlarını yordamasına ilişkin regresyon analizi sonucu

\begin{tabular}{lllllll}
\hline Değişkenler & $\mathrm{B}$ & Beta & $\mathrm{t}$ & $\mathrm{p}$ & $\mathrm{R}$ & $\mathrm{R}^{2}$ \\
\hline $\begin{array}{l}\text { Sayısal } \\
\text { Yetenek }\end{array}$ &, 722 &, 684 & 13,974 &, 000 &, $684^{\mathrm{a}}$ &, 468 \\
\hline
\end{tabular}

a.Predictors: (Constant), Matematik

Tablo 7'yi incelediğimizde $(B=, 722)$ değerinin pozitif olduğunu görmekteyiz ve anlamlılık değeri ise $(P=, 000) \quad 0,05$ anlamlılık değerinden küçük olduğu için sayısal yetenek beceri testi puanlarının fen bilimleri başarı puanları üzerinde pozitif yönde anlamlı bir etkiye sahip olduğunu söyleyebiliriz. 
$\mathrm{Bu}$ tabloda sadece bir bağımsız değişkenin (sayısal yetenek becerisi), bağımlı değişkeni (fen bilimleri başarısı) yordama etkisini incelediğimiz için $\mathrm{R}^{2}$ değerine bakmamız gerekir. $\mathrm{R}^{2}$ değeri ise bize; sayısal yetenek başarısının, fen bilimleri başarısı varyansının \%46,8'ini açıladığını söylemek mümkündür.

Tablo 8. İlköğretim 6.sınıf öğrencilerinin okuduğunu anlama ve yorumlama başarı notlarının fen bilimleri başarı notlarını yordamasına ilişkin regresyon analizi sonucu

$\begin{array}{llllllll}\text { Değişkenler } & B & \text { Beta } & t & p & R & R^{2}\end{array}$

\begin{tabular}{lllllll}
\hline $\begin{array}{l}\text { Okuduğunu } \\
\text { Anlama ve }\end{array}$, 461 &, 522 & 9,109 &, 000 &, $522^{\mathrm{a}}$ &, 272 \\
yorumlama & & & & & &
\end{tabular}

a.Predictors: (Constant), Turkce

Tablo 8'i incelediğimizde $(B=, 461)$ değerinin pozitif olduğunu görmekteyiz ve anlamlılık değeri ise $(\mathrm{P}=, 000) \quad 0,05$ anlamlılık değerinden küçük olduğu için okuduğunu anlama ve yorumlama testi puanlarının fen bilimleri başarı puanları üzerinde pozitif yönde anlamlı bir etkiye sahip olduğunu söyleyebiliriz.

$\mathrm{Bu}$ tabloda sadece bir bağımsız değişkenin (okuduğunu anlama ve yorumlama), bağımlı değişkeni (fen bilimleri başarısı) yordama etkisini incelediğimiz için $\mathrm{R}^{2}$ değerine bakmamız gerekir. $\mathrm{R}^{2}$ değeri ise bize; okuduğunu anlama ve yorumlama becerisinin, fen bilimleri başarısı varyansının \%27,2'sini açıkladığını söylemek mümkündür.

Tablo 9. İlköğretim 6.sınıf öğrencilerinin sayısal yetenek ve okuduğunu anlama ve yorumlama beceri notlarının fen bilimleri başarı notlarını yordamasına ilişkin regresyon Analizi Sonucu

\begin{tabular}{lccc}
\hline Değişkenler & $\mathrm{B}$ & $\mathrm{t}$ & $\mathrm{P}$ \\
\hline Sayısal Yetenek &, 610 & 9,677 &, 000
\end{tabular}

Okuduğunu Anlama ve

yorumlama

, 158

2,996

, 003

Tablo 9'u incelediğimizde sayısal yetenek testine ait $(B=, 610)$ değeri ile okuduğunu anlama ve yorumlama testine ait $(B=, 158)$ değerinin pozitif olduğunu görmekteyiz. Ayrıca her iki teste ait anlamlılık değerleri de $\left[(\mathrm{p} 1=, 000),\left(\mathrm{p}^{2}=, 003\right)\right] \quad 0,05$ anlamlılık değerinden 
küçük oldukları için sayısal yetenek testi puanları ile okuduğunu anlama ve yorumlama testi puanları birlikte değerlendirildiğinde fen bilimleri başarı puanları üzerinde pozitif yönde anlamlı bir etkiye sahip olduğunu söyleyebiliriz.

Tablo 9. (Devamı) İlköğretim 6.sınıf öğrencilerinin sayısal yetenek ve okuduğunu anlama ve yorumlama başarı notlarının fen bilimleri başarı notlarını yordamasına ilişkin regresyon analizi sonucu

\begin{tabular}{lllll}
\hline Değişkenler & Beta & $\mathrm{R}$ & $\mathrm{R}^{2}$ & Düzeltilmiş R \\
\hline $\begin{array}{l}\text { Sayısal Yetenek } \\
\text { Okuduğunu }\end{array}$ &, 578 &, $699^{\mathrm{a}}$ &, 489 &, 484 \\
Anlama ve &, 179 & & & \\
yorumlama & & & & \\
\hline
\end{tabular}

a.Predictors: (Constant), Matematik, Turkce

Ayrıca Tablo 9'a göre iki bağımsız değişkenin (1-Sayısal yetenek becerisi, 2Okuduğunu anlama ve yorumlama), bağımlı değişkeni (fen bilimleri başarısı) yordama etkisini incelemek için Düzeltilmiş $\mathrm{R}^{2}$ değerine bakmamız gerekir. Düzeltilmiş $\mathrm{R}^{2}$ değeri ise bize; sayısal yetenek başarı puanları ile okuduğunu anlama ve yorumlama beceri puanları birlikte, fen bilimleri başarısı varyansının \%48,4'ünü açıkladığını söylemek mümkündür.

\section{Tartışma, Sonuç ve Öneriler}

$\mathrm{Bu}$ araştırma 6.sınıf öğrencilerinin fen bilimleri dersi kuvvet ve hareket ünitesindeki sürat konusu ile ilgili hazırlanmış 20 maddelik akademik başarı testinin cevaplandırılmasında okuduğunu anlama ve yorumlama ile dört işlem becerilerinin etkisinin ne düzeyde olduğunu tespit etmek amacıyla yapılmıştır. Ayrıca öğrencilere uygulanan okuduğunu anlama ve yorumlama, dört işlem becerisini ölçen sayısal yetenek testi ve fen bilimleri dersi sürat konulu akademik başarı testinde öğrencilerin elde ettiği başarı sonuçlarının betimsel sonuçları ve testler arasındaki ilişki incelenmiştir.

Bu araştırmada öğrencilerin okuduğunu anlama, yorumlama ve dört işlem becerileri ile fen bilimleri başarıları arasında pozitif/olumlu yönlü bir ilişki olduğu sonucuna varılmıştır. $\mathrm{Bu}$ da bize; öğrencilerin, onlara sunulan konuları okuyup ve anlamlandırdıklarında ayrıca matematikteki dört işlem becerilerinin veya sayısal yetenek becerilerinin gelişmesiyle fen bilimleri derslerindeki akademik başarı oranının arttı̆̆ını göstermektedir. Benzer nitelikteki diğer çalışmalara baktığımızda ise şunları söyleyebiliriz; 
Bloom ve arkadaşlarının (1976) yapmış oldukları uluslararası bir çalışmada, okuduğunu kavrayabilme ile fen bilimleri arasında ortaokul seviyesinde 0,62'lik ve okuduğunu kavrayabilme ile matematik başarısı arasında yine ortaokul düzeyinde 0,72'lik oranında pozitif yönlü korelasyon bulunmuştur. Bu araştırmada ise benzer şekilde sonuçlara ulaşılmıştır (Akt: Coşkun, 2002).

Yakıcı (1994), yapmış olduğu araştırmada öğrencilerin ÖYS sonuçları ile deneme sınavı sonuçlarını karşılaştırmıştır. Çalışmasında öğrencilerin matematik başarıları ile fen bilimleri başarıları arasında anlamlı bir ilişki olduğu sonucuna ulaşmıştır. Bu çalışmada ise dersler arasındaki ilişkiye baktığımızda korelasyonun en yüksek olduğu iki disiplinin fen bilimleri ile matematik olduğunu söylemek mümkündür. Yakıcı'nın yapmış olduğu çalışma da bunu destekler mahiyettedir.

Akay (2004)'ın yapmış olduğu araştırmada kitap okuma etkinlikleri ile okuduğunu anlama ve yorumlama davranışını geliştiren öğrencilerin matematik problemlerini çözme başarıları bu davranışı geliştirmeyen öğrencilere göre daha yüksek olduğu sonucuna varılmıştır. Akay'ın bu araştırması matematikteki problem durumlarının çözümlenmesi noktasında, okuduğunu anlama ve yorumlamanın etkisini göstermesi hususunda büyük önem taşımaktadır. Bu araştırmada ise öğrencilere fen bilimleri dersinin kuvvet ve hareket ünitesinin 'sürat' konusunda sorulan sorular büyük ölçüde matematik bilgi ve becerilerini gerektirdiğinden dolayı okuduğunu anlama ve yorumlamanın bu soruları çözebilmede olumlu yönde etkisi olacağı söylenebilir -ki araştırmanın sonucu ve literatürdeki diğer araştırmalar bu sonucu destekler niteliktedir.

$\mathrm{Bu}$ araştırmada elde edilen sonuçlar doğrultusunda okuduğunu anlama ve yorumlama ile dört işlem becerisi, fen bilimleri dersi sürat konusundaki akademik başarı puanları üzerinde pozitif yönde anlamlı bir şekilde etki etmiştir. Türkçe ile fen bilimleri arasında orta düzeyde, matematik ile fen bilimleri arasında ise yüksek düzeye çok yakın pozitif bir ilişki olduğu görülmüştür. Bağımsız değişkenlerimizin (Türkçe ve Matematik), bağımlı değişeni (Fen Bilimleri) yordama gücüne baktığımızda ise okuduğunu anlama ve yorumlama becerisinin fen bilimleri dersi sürat konusundaki akademik başarıyı \%27,2 oranında yordamıştır. Dört işlem becerisinin ise fen bilimleri dersi sürat konusundaki akademik başarıyı \%46,8 oranında yordadığı sonucu ortaya çıkmıştır. Bu oranlara bakıldığında ise yine bu disiplinlerin birbirleri ile olan sıkı ilişkilerini görülmektedir. Matematiğin fen bilimleri dersi sürat konusundaki akademik başarıyı yordama gücünün 
\%50 ye yakın olması bu iki disiplin arasında mutlaka işbirliği yapılması gerekliliğini ortaya koymaktadır. Sürat konusu her ne kadar sayısal içerikli bir konu olsa da \%27,2 lik gibi bir yordama(açıllama) gücü, okuduğunu anlama ve yorumlama becerisinin fen bilimleri dersi sürat konusundaki akademik başarısı üzerindeki önemi yadsınamaz.

Elde edilen sonuçlar doğrultusunda bir takım öneriler verilecek olursa, Fen bilimleri başarısına, öğrencilerin dört işlem başarısının ve okuduğunu anlama, yorumlama becerilerinin etkisi dışında farklı etkenlerin de olabileceği konusunda araştırmalar yapılabilir. Mesela yapılan birçok araştırmada öğrencilerin; matematiğe karşı önyargı, umutsuzluk, korku, matematiği sevmeme gibi durumları, matematik başarılarını olumsuz yönde etkilediği görülmüştür (Aydın, 2003; Albayrak, 2000). Bu çalışmada da dört işlem becerisi ile fen bilimleri başarısı arasında yüksek bir ilişki bulunduğundan dolayı matematiğe karşı geliştirilen olumsuzlukların fen bilimlerine karşı da geliştirebilme ihtimali olabilir. Bu yüzden öğrencilerin, fen bilimlerine karşı umutsuzluk, korku, önyargı gibi düşüncelerinin olup olmadığı tespit edilebilir.

6. sınıf öğrencilerinin kuvvet ve hareket akademik başarı testindeki puanları üzerinde okuduğunu anlama ve yorumlama becerisinin büyük ölçüde etkisi olduğu sonucuna ulaşıldığından $[(R=27,2), \quad(r=0,522)]$ dolayı, fen bilimleri öğretmenleri ile Türkçe öğretmenleri arasında işbirliği yapılarak öğrencilerin okuma becerilerini geliştirecek çalışmalar yapılabilir.

Okumak ve okuduğunu anlamak, sadece Türkçe dersinin bir gerekliliği değildir. Öğrenciler, diğer derslerde de başarılı olabilmeleri için okumalarını geliştirmeli ve okuduklarını anlamlandırabilmeleri gerekmektedir. Bunun için öğrencilere okumayı sevdirecek ve onları okumaya teşvik edecek;

- Kitap okuma saatleri ve tartışma günleri düzenlenebilir.

- Okunan kitaplarla ilgili resim, drama, kısa film gibi yarışmalar düzenlenebilir.

- Kitap fuarı gezileri düzenlenerek öğrenciler yazarlarla buluşturulabilir.

- MEB tarafından ders kitaplarıyla birlikte öğrencilere birer roman hediye edilebilir. (Böylece Öğrencilerin güdülenme düzeyinin artması sağlanabilir.)

- Z-Kütüphanenin her okulda kurulması ve bu kütüphanede öğrencilerin ilgisini çekecek her ders ile ilgili dergi ve kitapların olması sağlanabilir.

- Mevcut kütüphanelerin daha dinamik bir yapıya kavuşması için çalışmalar yapilabilir. 
Bilgilendirme

Bu çalışmada kullanılan veriler 2020 yılı öncesine ait olduğu araştırmacılar tarafindan onaylanmıştır.

Yazar Katkı Beyanı

İbrahim KARASU: Kavramsallaştırma, Kavramsal çerçeve, istatistik analizler, Ölçme Aracı Geliştirme, Veri Toplama ve Analizi, Ön Taslak Yazımı ve Düzenleme

Mehmet Akif HAŞILOĞLU: Kavramsallaştırma, Metodoloji, Danışmanlık ve Denetim Inceleme-Yazma ve Düzenleme, Kaynak tarama

\section{Kaynaklar}

Albayrak, M. (2001). İlköğretim okullarının I. kademesinden II. kademesine geçişte matematik eğitimi ile ilgili ortaya çıkan sorunlar. IV. Fen Bilimleri ve Matematik Eğitimi Kongresi Tam Metin Kitabı (s. 513-517) içinde. Ankara: MEB Basım Evi.

Aydın, B. (2003). Bilgi toplumu oluşumunda bireylerin yetiştirilmesi ve matematik öğretimi. Pamukkale Üniversitesi Ĕ̆itim Fakültesi Dergisi, 2(14), 183-190.

Balc1, A. (2015). Sosyal bilimlerde araştırma yöntem, teknik ve ilkeler (11. Baskı). Ankara: Pegem Akademi Yayıncilık.

Bütüner, S.Ö. \& Uzun, S. (2011). Fen öğretiminde karşılaşılan matematik temelli sıkıntılar: Fen ve teknoloji öğretmenlerinin tecrübelerinden yansımalar. Kuramsal Eğitim Bilim Dergisi, 4(2), 262-272.

Büyüköztürk, Ş. Kılıç-Çakmak, E. Akgün, Ö. Karadeniz, Ş. \& Demirel, F. (2013). Bilimsel araştırma yöntemleri (14.baskı). Ankara: Pagem Akademi.

Büyüköztürk, Ş., Çakan, M., Tan, Ş. \& Atar H. Y. (2014). TIMSS 2011 ulusal matematik ve fen raporu: 8.sınıflar. Millî Eğitim Bakanlığı Yenilik ve Eğitim Teknolojileri Genel Müdürlüğü, Ankara: MEB. Erişim Adresi: http://timss.meb.gov.tr/wpcontent/uploads/TIMSS-2011-8-Sinif.pdf

Cereno, A. (1998). İlköğretim okulları matematik programının merkez okulları ile taşımalı eğitim yapan okullarm 4. ve 5.sinflarmdaki dört işlem, kümeler, kesirler konularma ait hedef ve hedef davranışların gerçekleşme düzeyi (Yayımlanmamış yüksek lisans tezi). Abant İzzet Baysal Üniversitesi, Sosyal Bilimler Enstitüsü, Bolu.

Ciminli-Oktay, E. (2013). Sınıf fen ve teknoloji dersinin yaşamımızdaki sürat konusundaki matematik becerileri üzerine öğrenci ve öğretmen görüşlerinin incelenmesi (Yayımlanmamış yüksek lisans tezi). Erzincan Üniversitesi, Fen Bilimleri Enstitüsü, Erzincan.

Coşkun, E. (2002). Lise hızlı okuma teknikleri öğretim programı ve uygulamalarının değerlendirilmesi. Eurasian Journal of Educational Research, 9, 41-51.

Deveci, Ö. (2010). İlköğretim altıncı sınıf fen ve teknoloji dersi kuvvet ve hareket ünitesinde fenmatematik entegrasyonunun akademik başarı ve kalıcılık üzerine etkisi (Yayımlanmamış yüksek lisans tezi). Çukurova Üniversitesi, Sosyal Bilimler Enstitüsü, Adana. 
George, D. \& Mallery, M. (2010). SPSS for windows step by step: A simple guide and reference (17.0 update 10th ed.). Boston: Pearson.

Güleç, S. \& Alkış, S. (2003) İlköğretim birinci kademe öğrencilerinin derslerdeki başarı düzeylerinin birbiriyle ilişkisi. İlköğretim Online, 2 (2), 19-27.

Karasar, N. (2000). Bilimsel araştırma yöntemi (10.basım). Ankara: Nobel Yayın Dağıtım.

Kutlu, Ö., Yıldırım, Ö., Bilican, S. \& Kumandaş, H. (2011). İlköğretim 5. sınıf öğrencilerinin okuduğunu anlamada başarılı olup-olmama durumlarının kestirilmesinde etkili olan değişkenlerin incelenmesi. Eğitimde ve Psikolojide Ölçme ve Değerlendirme Dergisi, 2(1), 132-139.

Milli Eğitim Bakanlığı [MEB]. (2015). PISA 2012 ulusal nihai raporu. Millı̂ Eğitim Bakanlığı, Ölçme, Değerlendirme ve Sınav Hizmetleri Genel Müdürlüğü, Ankara: MEB. Erişim Adresi: https://drive.google.com/file/d/0B2wxMX5xMcnhaGtnV2x6YWsyY2c/view

Milli Eğitim Bakanlığ1 [MEB]. (2006). PISA 2006 ulusal nihai raporu. Millî Eğitim Bakanlığı, Ölçme, Değerlendirme ve Sınav Hizmetleri Genel Müdürlüğü, Ankara: MEB. Erişim Adresi: http://pisa.meb.gov.tr/wp-content/uploads/2013/07/PISA2006-Ulusal-Nihai-Rapor.pdf Milli Eğitim Bakanlığı [MEB]. (2010). PISA 2009 ulusal ön raporu. Millî Eğitim Bakanlı̆̆ı, Ölçme, Değerlendirme ve Sınav Hizmetleri Genel Müdürlüğü, Ankara: MEB. Erişim Adresi: http://pisa.meb.gov.tr/wp-content/uploads/2013/07/PISA-2009-Ulusal-On-Rapor.pdf

Osborne, J. W. \& Overbay, A. (2004). The power of outliers (and why researchers should always check for them). Practical Assessment, Research, and Evaluation, 9(6),1-8.

Pakyürek-Karagöz, M. (2008). İlköğretim fen ve teknoloji dersi "kuvvet ve hareket" ünitesinin probleme dayalı öğrenme yaklaşımıla öğretiminin öğrencilerin bilimsel süreç becerileri, başarıları ve tutumları üzerine etkisi (Yayımlanmamış yüksek lisans tezi). Muğla Üniversitesi, Fen Bilimleri Enstitüsü, Muğla.

Sever, S. (1993). Türkçe öğretiminde uygulanan tam öğrenme kuramı ilkelerinin okuma ve yazılı anlatım becerilerindeki erişiye etkisi (Unpublished dissertation). Ankara Üniversitesi Sosyal Bilimler Enstitüsü, Ankara.

Şad, S. N. (2012). Investigation of parental İnvolvement tasks as predictors of primary students' turkish, math, and science and technology achievement. Eurasian Journal of Educational Research, 49, 173-196.

Yakıcı, A., (1994). Liselerde matematik puanının fen, türkçe ve sosyal puanları arasındaki ilişkileri (Yayımlanmamış Yüksek lisans tezi). Hacettepe Üniversitesi, Ankara. 